cytoplasm. The Gin Rin fish had a much greater density of iridophores, each containing more stacks of crystals than in the common type. The Gin Rin crystals were also oriented differently almost parallel to the surface of their scales instead of at an angle of around $30^{\circ}$, as in the common variety.

J. Am. Chem. Soc. http://doi.org/ xd8 (2014)

\section{GEOLOGY}

\section{Europe feels fracking shakes}

Hydraulic fracturing during natural-gas extraction caused two earthquakes in the United Kingdom that were felt by residents, by reactivating a geological fault that had lain dormant for many millions of years.

'Fracking' involves injecting a mixture of water, sand and chemical additives into the ground to fracture rock and loosen trapped natural gas. Earthquakes induced by the process in North America have been felt by communities, but this is the first such example in Europe.

A team led by Huw Clarke of fracking company Cuadrilla Resources in Lichfield, UK, reports that fracking in 2011 near Blackpool caused earthquakes on 1 April and 27 May of magnitudes 2.3 and 1.5, respectively. Fluid injected during the fracking

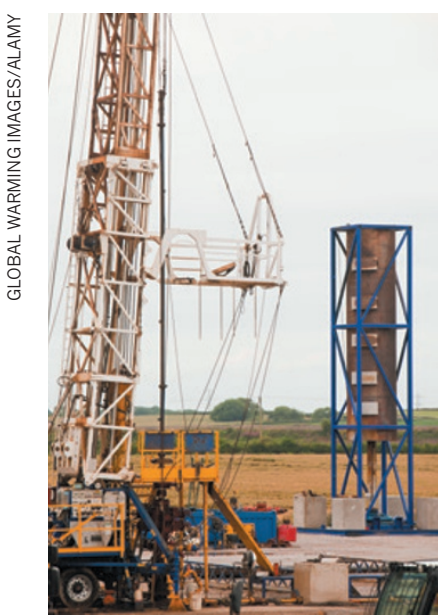

operation (pictured) caused movement in a fault that had been inactive for 260 million years.

Geophys. Res. Lett. http://doi. org/xc9 (2014)

CANCER IMMUNOLOGY

\section{Predicting cancer- therapy success}

Tumour-cell genomes may hold clues to who will benefit from treatments that stimulate the immune system against melanoma.

A protein called CTLA-4 on the surface of cancerfighting T cells can suppress these immune cells' attacks on the tumours. Drugs that block this protein can, in some patients, unleash these cells, but can have toxic side effects. Jedd Wolchok and Timothy Chan of the Memorial Sloan Kettering Cancer Center in New York and their colleagues sequenced genes in tumour cells from 64 patients with melanoma who were treated with CTLA-4 inhibitors.

Patients whose tumours had a higher number of cancer-associated mutations were more likely to benefit from the drugs, and a set of 101 tumour proteins created by these mutations were associated with a strong response to the drugs.

N. Engl. J. Med. http://doi.org/ xdx (2014)

\section{STEM CELLS \\ Matched stem cells still rejected}

Transplants of stem cells with nuclear DNA identical to that of a patient could still trigger immune responses because of the presence of mismatched mitochondria.

Sonja Schrepfer at Stanford University in California and her colleagues transferred nuclei from a donor mouse's adult cells into mouse embryonic stem cells with genetically matched nuclear DNA but different mitochondrial DNA. When

\title{
SOCIAL SELECTION Romiarancieas
}

\section{Unequal fates for maths superstars}

A gift for numbers can take a person far in life, according to a report getting plenty of online attention. A survey of 1,004 men and 601 women who were identified as 13-yearold mathematics prodigies in the 1970s found above-average levels of accomplishment in fields including business and academia. "How do things turn out for math prodigies? Pretty well, it seems," tweeted Tyler Cowen, an economist at George Mason University in Fairfax, Virginia. Cowen told Nature that he shared the report on Twitter because he suspects that many of his followers have gifted children. "I was delivering good news," he says.

However, success was not evenly distributed. On average, the women in the survey earned about US $\$ 80,000$ a year. That is more than double the amount that US women with full-time jobs typically make in a year, but about $\$ 60,000$ less than the men in the survey. Zhana Vrangalova, a sexuality researcher at New York University in New York City, summed it up on Twitter by noting that the survey participants had accomplished "a lot more than the average Jo/Jane".

Psychol. Sci. http://doi.org/xfb (2014)

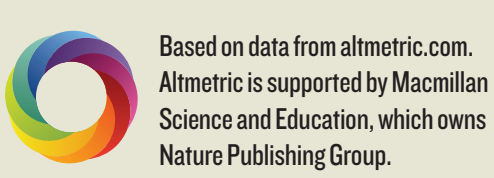

ONATURE.COM

For more on popular papers: go.nature.com/ee3r5w the cells were transplanted back into the donor, they were attacked by the immune system. Isolated mismatched mitochondria also triggered an immune response. Cell Stem Cell 16, 1-6 (2015)

\section{CANCER BIOLOGY}

\section{Tumours set stage for their spread}

An intricate interplay between cancer cells and white blood cells outside a lung tumour can help to drive metastasis, the spread of the disease to other parts of the body.

Nathan Reticker-Flynn and Sangeeta Bhatia at the Massachusetts Institute of Technology in Cambridge focused on a molecule called galectin-3, which they found is expressed on the surface of certain white blood cells during early cancer in mice. Lung tumours secrete signalling molecules that mobilize these white cells known to promote metastasis - out of the bone marrow and into the bloodstream.

Metastatic cells from the tumour display a cell-surface sugar that binds to galectin-3. As a result, these cells increasingly interact with the mobilized white blood cells in distant parts of the body, enhancing the cancer cells' ability to colonize and grow into new tumours.

Cancer Discov. http://doi.org/xdf (2014)

\section{CORRECTION \\ The Research Highlight 'Fish tags guide seal predators' (Nature 515, 469; 2014), gave the wrong year for the citation; it should have been 2015.}

\section{$\rightarrow$ NATURE.COM}

For the latest research published by Naturevisit:

www.nature.com/latestresearch 